\title{
COLLECTIBILITY IMPROVEMENT IN PT. KALTIM PRIMA COAL RECEIVABLES MANAGEMENT: A FRAMEWORK ROADMAP PROPOSAL
}

\section{Zuhri Ruslan and Anggoro Budi Nugroho}

Bandung Institute of Technology, Indonesia

E-mail: zuhri.ruslan@sbm-itb.ac.id dan anggoro@sbm-itb.ac.id

\section{Received:}

December $26^{\text {th }}$

2021

Direvisi:

January $10^{\text {th }} 2022$

Disetujui:

January $15^{\text {th }} 2022$

\section{Abstract}

Background : The Importance of efficient working capital management is indisputable given that a firm's viability relies on the financial manager's ability to effectively manage receivables, inventory, and payables. One of widely used measurement to calculate the effectiveness of working capital management is Cash Conversion Cycle. Purpose : Traditional Cash Conversion Cycle is calculated using items from Financial Statement. However, it is proofed to be overstated compare to the actual calculation. Based on a comparison with Cash Conversion Cycle of another company listed on Indonesian Stock Exchange, Cash Conversion Cycle of PT Kaltim Prima Coal seems to be superior with lower days it needs to convert inventory into cash and longer time to pay its payables. Method: This research uses a quantitative approach method. Results : The research found that based on the regression method, days of late payment and sales amounts of late payment have significant relationship with Profit. Days of late payment and sales amounts of late payment have significant relationship with ROA. And, Days of late payment and sales amounts of late payment also have significant relationship with NPM. Conclusion : PT. Kaltim Prima Coal are recommended to implement analysis of Risk Quadrant on periodic basis, to arrange Letter of Credit training to adopt Company Bank's point of view in reviewing the Letter of Credit, to implement Letter of Credit checklist to reduce discrepancy rate, to arrange objective review of examining the extra staff requirement, and to develop Credit Policy.

Keywords: Cash Conversion Cycle, Working Capital Management, Roadmap

\section{Introduction}

The relation between Working Capital Management and Profitability at least can be explained in three ways (Ponsian, Chrispina, Tago, \& Mkiibi, 2014). If company does not pay its liabilities, it will increase profitability. If company pays lot of its liabilities, the profit will be reduced. If the company does not manage its Working Capital well, it may not able to meet their short term financial obligations. It happens, the suppliers of the company will stop supplying goods and services that company needs to create inventory and sell to the market. No sales will reduce profitability (Christopher, 2016). On the contrary, if company can manage its Working Capital, company can continue producing or even increase its production and sells more (Takon \& Atseye, 2015). Thus, it is able to increase its profitability. If company does not manage its Working Capital well and not 


\section{Collectibility Improvement In PT. Kaltim Prima Coalreceivables Management: A Framework Roadmap Proposal}

able to meet their short-term financial obligations, their creditors will seek legal assistance to collect their dues. This will affect reputation of the company and lead to a decrease in sales (Ganesamoorthy \& Rajavathana, 2013).

Understanding relation between Working Capital Management and its impact on company profitability will give useful information in managing account receivable, inventory and account payable of the company thus company can survive and provide value-added for the shareholder in the long run (Edmans, 2011). Hence, this research has three purposes. First, is to examine the relation of Working Capital Management with Profitability in PT Kaltim Prima Coal (KPC) for the year 2008-2013. Second, is to examine the structure of risks exposing KPC regarding Working Capital Management. And third, is to investigate any possible action to improve Working Capital. Specifically, is to enhance the speed of collection receivable from customers.

Global Coal Market nowadays faces a challenging situation with the price suffering from a downtrend since 2008 (Xia \& Tang, 2011). Many have suffered and liquidated their company, closed the operational even went bankrupt. The price fall was mainly caused by two factors. First, the innovation of using natural gas as substitute of Coal powered electric generator in United States (Liang, Ryvak, Sayeed, \& Zhao, 2012). Natural gas is considered cheaper in the long run and clearer or eco-friendly. Second, China limited its amount of coal import which then made global coal market suffer from oversupply (Zhao \& Alexandroff, 2019). As the consequences, the price went fall significantly and reduce the margin of the company (Cornot-Gandolphe, 2014). Company will sell at a lower price, while the cost stays the same. The decreasing margin will eventually trouble the working capital management.

Hence, coal companies have to carefully manage their working capital. If they make a mistake, the worst case scenario is company will not have any funds left to fulfill its liability. The creditor and supplier will use legal approach to claim their receivables. If they can manage working capital better, not just the company will survive through difficult times, perhaps still can show some profit to its shareholder. This extremely important position of working capital management makes it as one of the financial manager's most important and time-consuming activities, and more than one half of the financial manager's time is spent managing account receivables and account payables (Gitman \& Tyutin, 2012).

The impact of a price decrease on collection the receivable is collection is lower, and now the longer time is needed to collect the receivable and the amount (Van der Vliet, Reindorp, \& Fransoo, 2015). These increase risk in KPC because the collection is not able to meet the liabilities needs to be paid every week (Weil, 2014). To our best knowledge, the research of how much Working Capital Management affect Profitability of KPC has never been conducted before, and considering KPC should maintain its profitability in the mid downtrend of coal price imposes the importance of this research.

\section{Research methods}

The method used is the descriptive text analysis method used to identify the form of changes that occur in the transfer of the material object. This method limits its activities to library collection materials without the need for field research. The steps of the research work consisted of collecting data, processing data, and presenting the results of the analysis. 
Volume 2, Nomor 1, Januari 2022

p-ISSN 2774-7018; e-ISSN 2774-700X

\section{Results and Discussion}

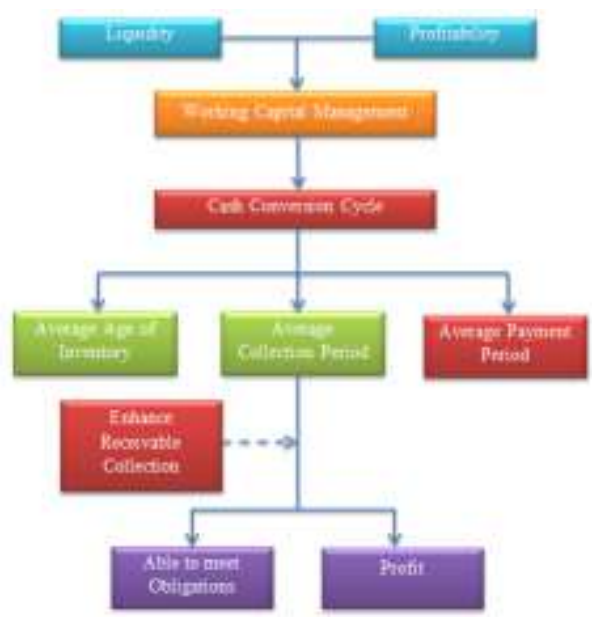

Figure 1. Conceptual Framework

How to increase Profitability and liquidity is always the focus of good working capital management. One of the most used working capital management measures is Cash Conversion Cycle. Cash Conversion Cycle measures the Average Age of Inventory, Average Collection Period, and Average Payment Period (Malik \& Bukhari, 2014). When the date of Age of Inventory is not available, and Payment period already delay as long as possible, improvement focus should be on faster Collection Period. The project to enhance and speed up collection will result in the ability of the company to fulfill its short-term and long-term obligations, and hypothetically will increase profit.

Considering KPC has received payment exceeding the day stipulated in the contract, root-cause analysis is performed to search the root of the problems (Teachout, 2020). The structure of the problem appears from discussion with Superintendent Accounting and Administration in Marketing Department who is handling the Invoicing process. The next page shows the fishbone root-cause analysis, and findings of several root causes are as of following: 
Collectibility Improvement In PT. Kaltim Prima

Coalreceivables Management: A Framework Roadmap

Proposal

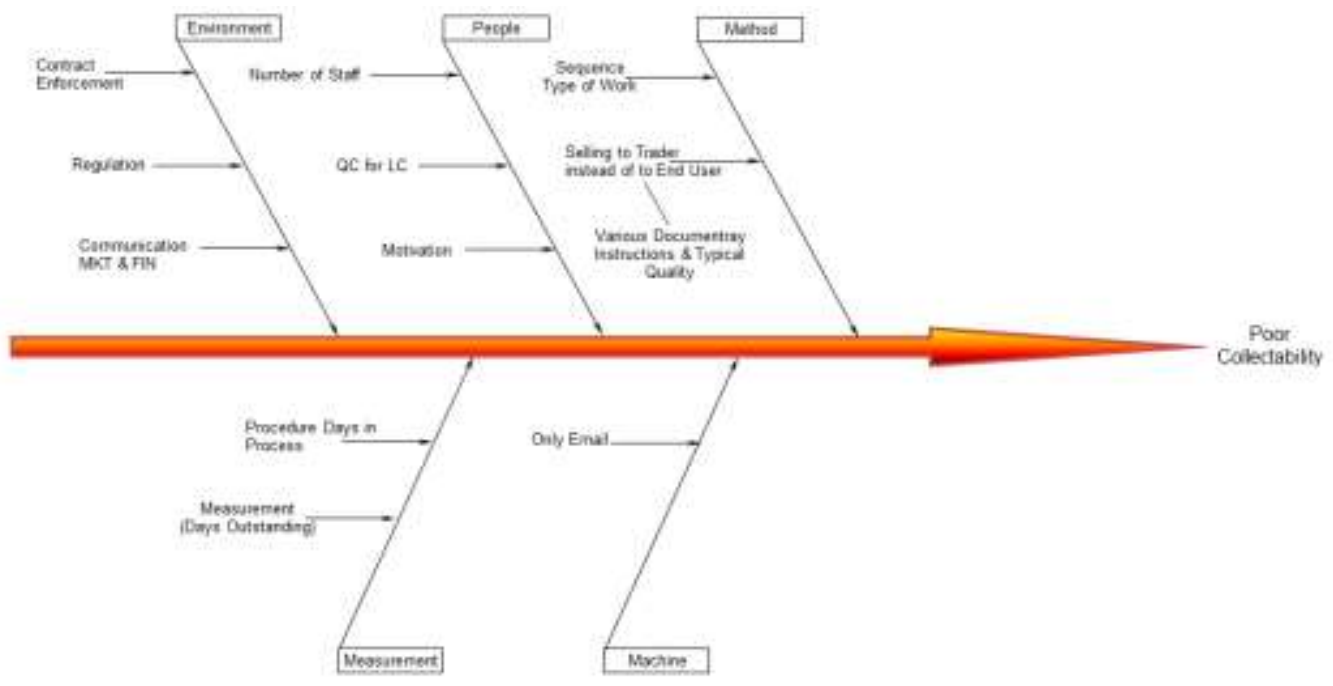

Figure 2. Root Cause Analysis 
There are several reasons why poor collectibility happens. They are:

1. Sequence Type of Work.

Invoicing process is at the end of work cycle. The prior process is establishing contract, arranging Ship Scheduling, Blending and Coal Quality process, and Coal loading. Sales Accounting and Administration Section is the section that handles invoices and documentation. They are at the end of the process and any delay in the earlier process will also cause the delay in preparing a document for the collection process.

2. Selling to Trader instead of to End User.

KPC not only sell the coal to the end user but also expand its customer range to a trader, which later will sell the coal to the end user or to another trader.

3. Reconsider the Number of Staff.

The number of staff is quite tight and as the workload increase mistakes may happen. Even little mistakes such send one original set of certificate of analysis instead of three as contract asked will cause incomplete document, and customer will not start to pay if the document is incomplete.

4. Letter of Credit Discrepancy (LC)

$\mathrm{LC}$ is a document issue by a bank in relation to provide security for buyer and seller in exchange of goods and payment. In LC scheme, buyer's bank and seller's bank will credibility of the buyer and the seller. Simply said, the benefits of using LC are the buyer will buy the correct goods, and the seller will receive right amount of cash payment.

Generally, the discrepancy rate is really high. Roughly $80 \%$ of the LC was found to be discrepant. It the LC is discrepant, company cannot discount the LC and receive the cash faster. The company has to wait for the customer pay to Issuing Bank, and then Issuing Bank will send the cash to Advising Bank, which later on will send the cash to the company. There is an urgent need for a project to reduce the discrepancy rate of LC.

5. Motivation

When employees are given a target, they tend to overcome the target with extra effort.

6. Contract Enforcement

The normal contract will have clause that if the payment is not paid on the due date there shall be an interest charge applied for the payment until the payment is paid. However, the enforcement of this clause is always a subject to Management approval and depends on the relationship between KPC and the customer.

7. Regulation

Some government regulations required time to fulfill and will cause delay to the completion of the invoice and supporting documents which later will delay the day payment received in KPC's bank.

8. Communication between Marketing and Finance.

The function of Account Receivable is also normally under Finance Division not under Marketing Division. This structural type creates may conflict between Marketing Division and Finance Division.

9. Procedure Days in Process

The faster Sales Accounting and Administration complete the invoice and documentation process, the faster documents are ready to be sent, and the faster the 
due date will be since the due date will be counted starting from the date KPC present correct invoice and supporting documentation.

10. Measurement Days Sales Outstanding.

KPC not yet use Days Sales Outstanding as a Key Performance Indicator.

The faster KPC receives the payment from the coal customer, the better for KPC. The funds can be used to pay off some of its debt in the next month i.e. leasing, special term contractor payment, etc. Thus, strengthen the Account Receivable collection function is the most important thing to do.

Cash Conversion Cycle consists of three components. First component is Average age of Inventory which calculates how many days KPC need to convert extracted coal into sales and Account Receivable. KPC at the moment did not calculate this. Second component is average Collection period which calculates how many days company need to claim its Account Receivable (Gul et al., 2013). In KPC, this is different for each customer. Some customers pay a week after receiving the invoice and its supporting document, while another supplier pay more than a week after the bill of lading date. The third component is Average payment period which calculates how long KPC paying its liabilities.

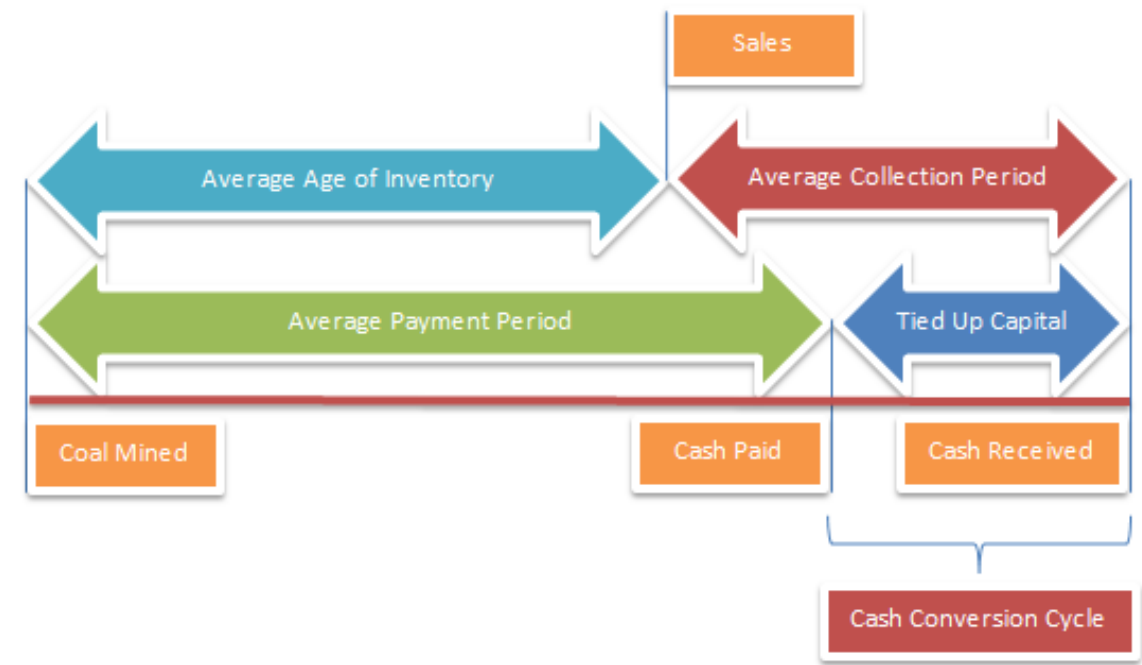

Figure 3. Cash Conversion Cycle diagram

The lower the number of Cash Conversion Cycle, the lower the amount of tied up capital. The best practice is to have zero tied up capital or even surplus tied up capital. And it means collection is received first before making any payment to supplier. However, this is rare and the target of this research is to reduce KPC's Cash Conversion Cycle ratio as lower as possible. Poor collectibility is shows as longer average collection period. The effect is more tied up capital locked as account receivables. Picture below explains poor collectibility.

Calculation of Cash Conversion Cycle calculation based on Financial Statement will be put in comparison to Cash Conversion Cycle calculation based on physical movement and cash received or pay by KPC. Calculation of Actual physic Average Age of Inventory is not possible to do since no data available for goods like coal. Average Collection Period is calculated by measure how many days payment received in bank from Bill of Lading date. There are significant different in collection days between Domestic Average Collection Period and other KPC export market customer. 
Calculation of Average Payment Period is calculated by collecting data from Ellipse system which show the "invoice date" and "update as paid" date. Invoice date is a date invoice being payable to KPC. The date KPC received the invoice from the supplier usually not very different from the invoice date. The update as paid date means the date KPC claim in the system that the invoice will be paid in one or two days which is the day needed for banking process to remit that payment to the supplier's account. 59,817 invoices with period form 1st January 1997 to 31st December 2014 were used. The different from Invoice date and update as paid date is the actual Payment Period. The differences between Average Collection Period and Average Payment Period using Financial Statement calculation and using actual calculation provided below:

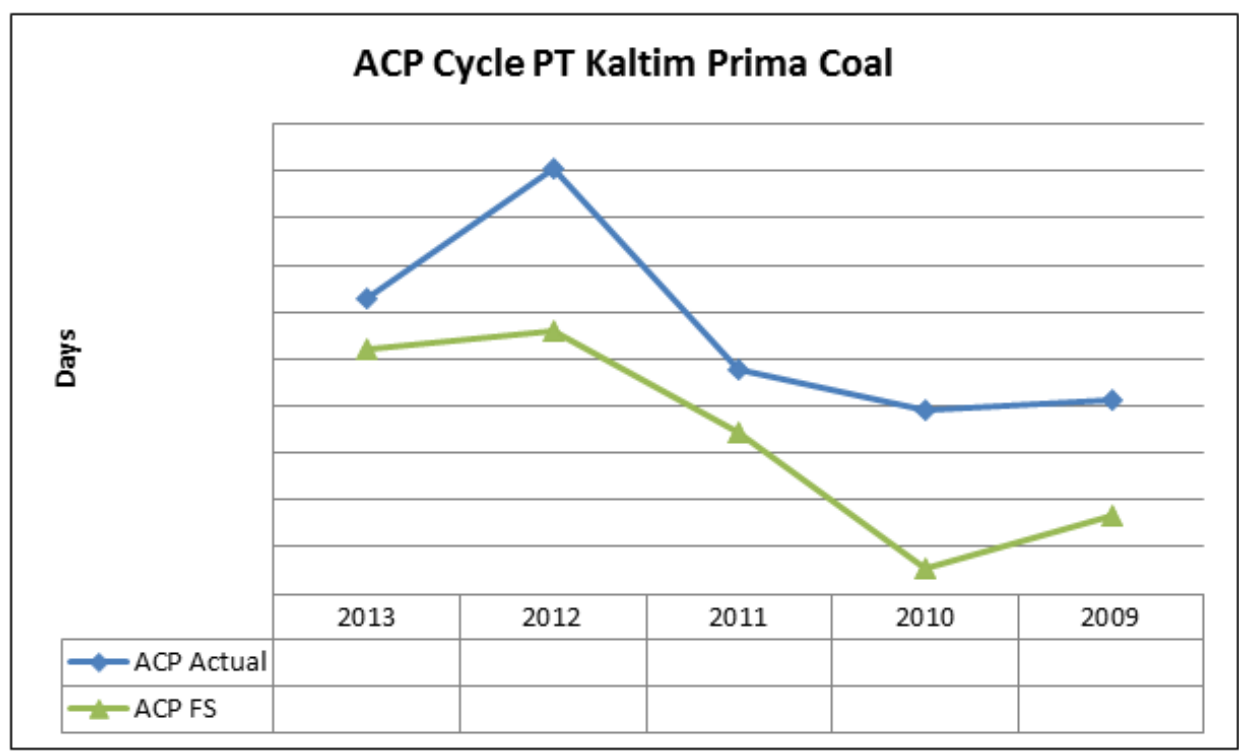

Figure 4. Comparison ACP Calculated from Financial Statement and Actual Days Cash Collected.

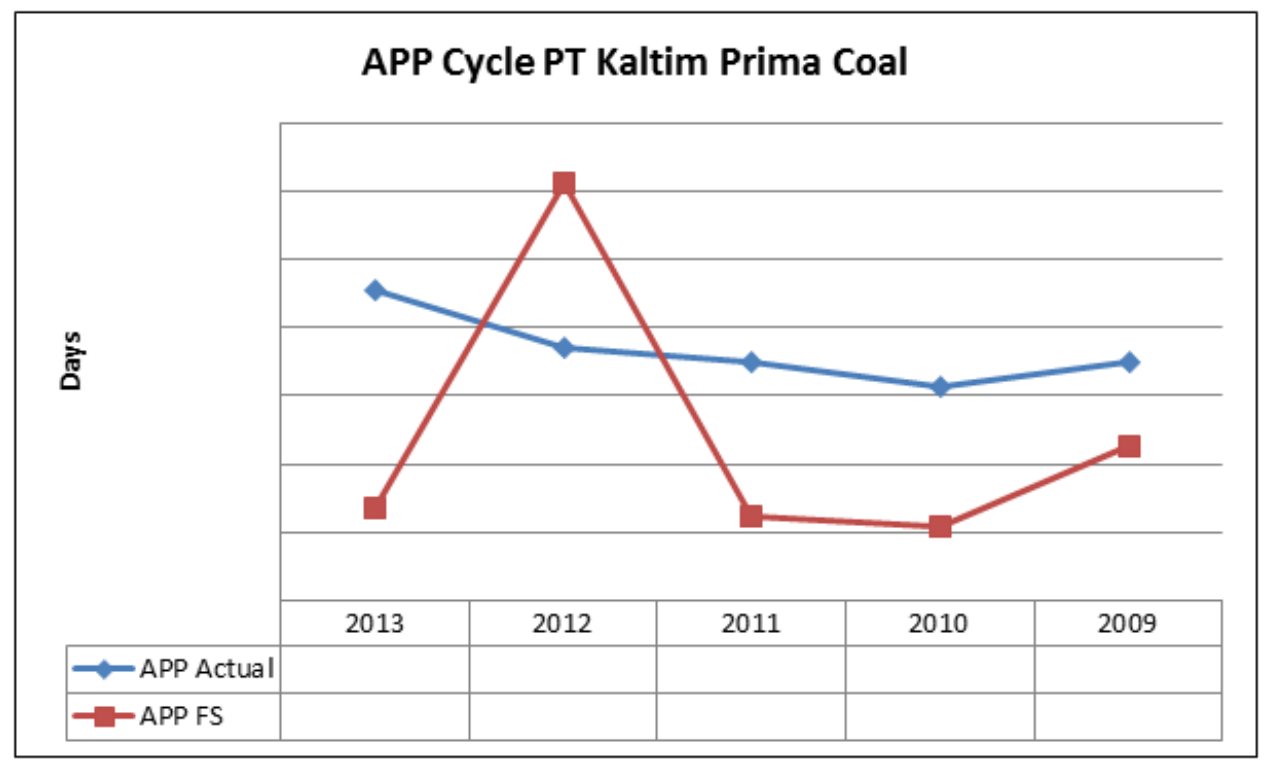

Figure 5. Comparison APP Calculated from Financial Statement and Actual Payment. 
The differences of Cash Conversion Cycle using Financial Statement calculation and using actual calculation provided below:

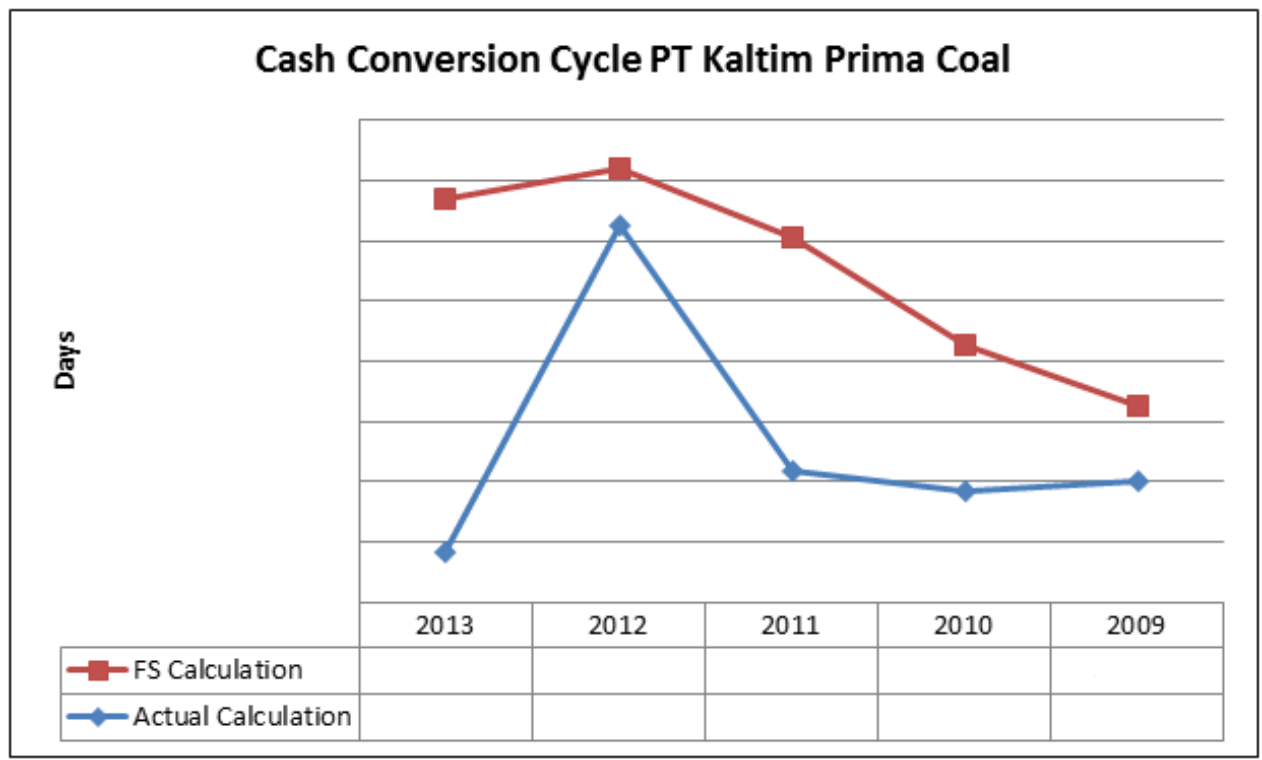

Figure 6. Comparison CCC Calculated from Financial Statement and Actual Days.

Clearly show above that the Cash Conversion Cycle from Financial Statement calculation is overstated compare to actual Cash Conversion Cycle that counted physically.

Based on the Audited Financial Statement 2009 to 2013 that available on www.idx.co.id below are the calculations of Cash Conversion Cycle. Comparison is made between same industry (Coal Mining) and from different industry (Plantation, Crude Oil, Nickel, Cement, Tire). Each company was selected based on the highest price of each industry, except for PT. Adaro Energy Tbk. and PT. Berau Coal Energy Tbk.. They are taken because they also major players in the industry and have same background with $\mathrm{KPC}$ which is mine operation conducted in Kalimantan.

\begin{tabular}{|c|c|c|c|c|c|c|c|}
\hline \multirow{2}{*}{ Stock Code } & \multirow{2}{*}{ Company } & \multirow{2}{*}{ Industry } & \multicolumn{5}{|c|}{ Year } \\
\hline & & & 2013 & 2012 & 2011 & 2010 & 2009 \\
\hline ADRO & PT. Adaro Energy Tbk. & Coal Mining & (6) & 3 & (8) & (12) & (9) \\
\hline BRAU & PT. Berau Coal Energy Tbk. & Coal Mining & (2) & 21 & (4) & (3) & 17 \\
\hline ITMG & PT. Indo Tambangraya Megah Tbk. & Coal Mining & 19 & 26 & 23 & 19 & 21 \\
\hline BYAN & PT. Bayan Resources Tbk. & Coal Mining & 4 & 10 & 17 & (9) & (9) \\
\hline PTBA & PT. Tambang Batubara Bukit Asam (Persero) Tbk. & Coal Mining & 67 & 83 & 77 & 76 & 93 \\
\hline AALI & PT. Astra Agro Lestari Tbk. & Plantation & 4 & 36 & 13 & 21 & 39 \\
\hline APEX & PT. Apexindo Pratama Duta Tbk. & Crude Oil & 91 & 58 & 44 & 77 & 94 \\
\hline INCO & PT. Vale Indonesia Tbk. & Nickel & 61 & 76 & 59 & 69 & 107 \\
\hline INTP & PT. Indocement Tunggal Prakarsa Tbk. & Cement & 66 & 72 & 86 & 87 & 103 \\
\hline GDYR & PT. Goodyear Indonesia Tbk. & Tyre & 22 & 28 & 26 & 33 & 53 \\
\hline
\end{tabular}

Figure 7. Cash Conversion Cycle Comparison KPC with Other Listed Company. 
Presented as graphic is as below:

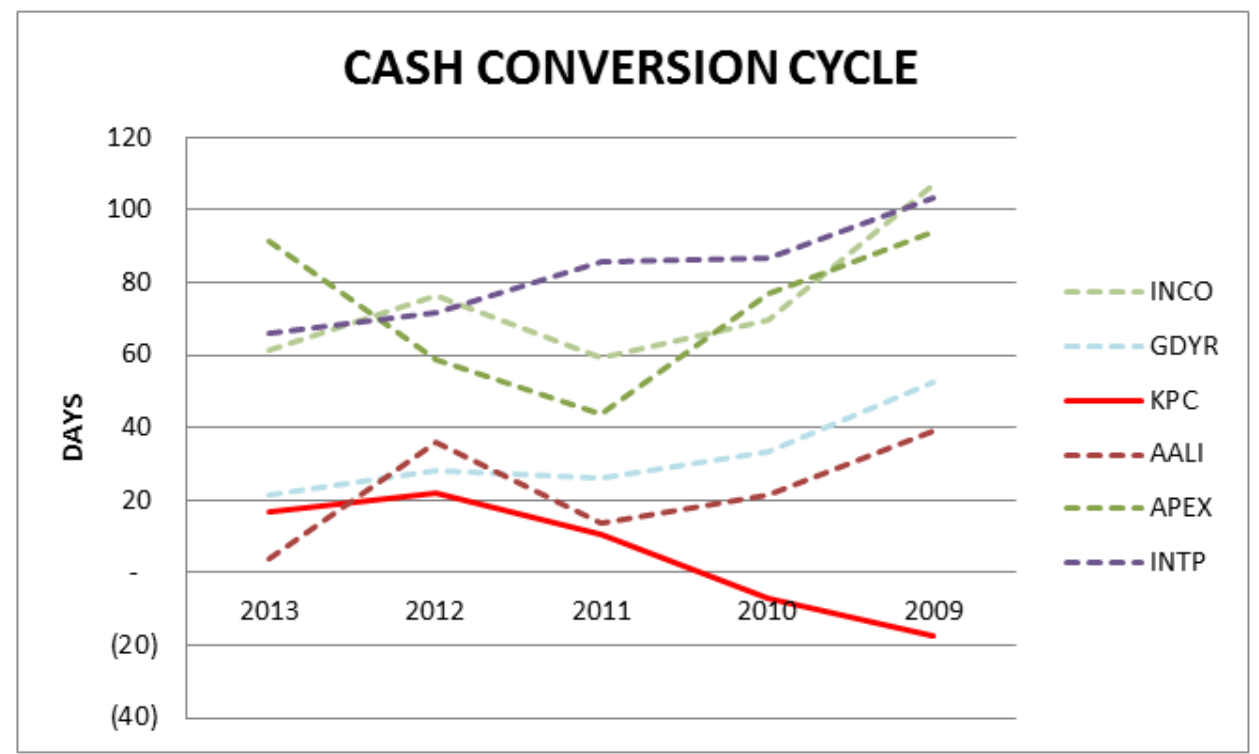

Figure 8. Cash Conversion Cycle Comparison KPC with Other Non-Coal Listed Company.

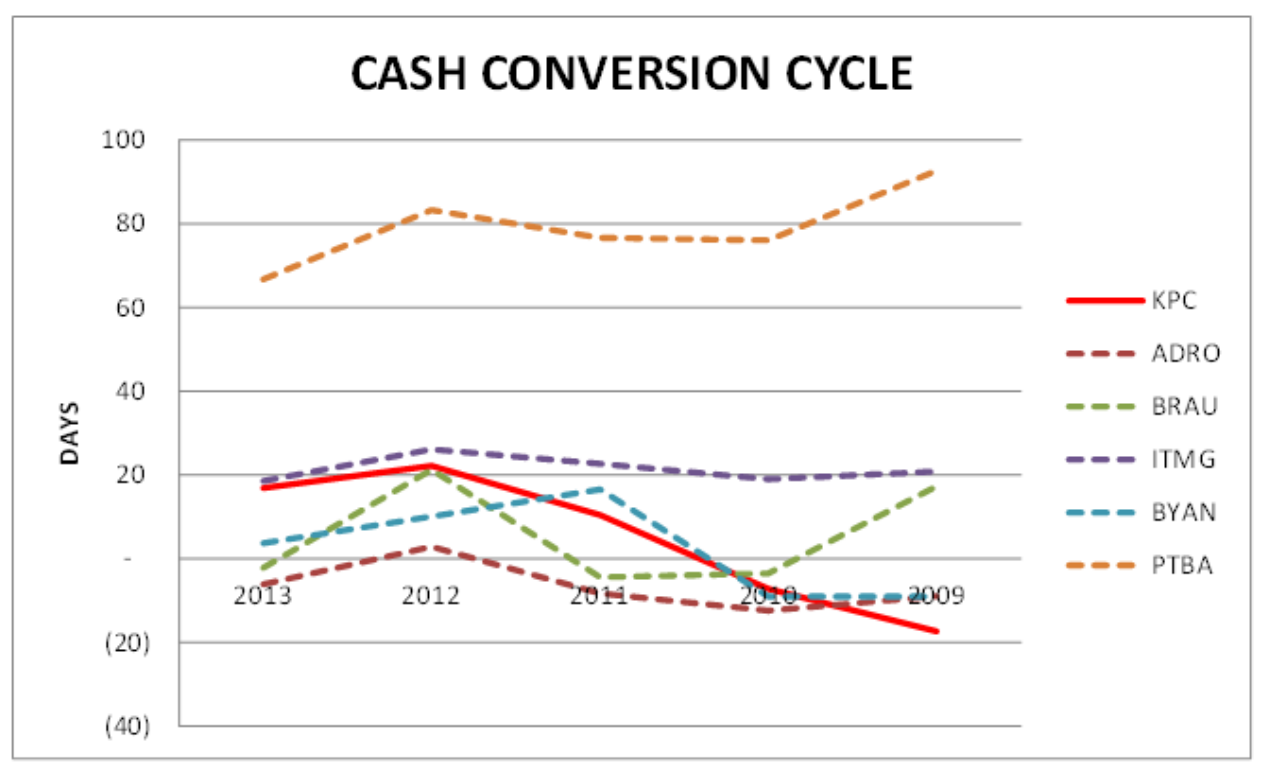

Figure 9. Cash Conversion Cycle Comparison KPC with Other Coal Listed Company.

According to the table, coal mining industry has relatively low cash conversion cycle compare to other industry, except plantation industry. That means coal mining company can have lower cash available to pay its due liabilities before received cash from the customer compare to another industry. For Example, KPC have cash conversion cycle 26.33 days on 2013. That means, KPC must have enough cash to operate the mine and pay its liabilities for 26.33 days before received cash for sold inventory. PT. Berau Coal Energy Tbk. has the best cash conversion cycle which is negative number -2.2 days. 


\section{Collectibility Improvement In PT. Coalreceivables Management: A Fram Proposal}

Meaning, PT. Berau Coal Energy Tbk. does not need to have cash available since it will receive cash from the customer before their liabilities due in the next 2.2 days. The longest cash conversion cycle is PT. Apexindo Pratama Duta Tbk 91.44 days. This hurt cash availability, since PT. Apexindo Pratama Duta Tbk. must have larga cash to cover production for nearly 3 months before receive cash from its customer. This is ineffective, since that much cash better be allocated to another activity like expansion or investment.

Interview efforts has been conducted to interview PT. Adaro Energy Tbk., PT. Bayarn Resources Tbk., PT. Berau Coal Energy Tbk., PT. Indotambang Megah Raya Tbk., and PT. Bukit Asam (Persero) Tbk. considering those companies are within same industry with KPC and have approximately same size. The interview efforts were found to be unresponded until the study is finalized.

\section{Conclusion}

Based on research question stipulated before, the study found:

1. Sensitivity analysis using linear regression provide proof that there are impact of poor collectibility to Profit / Loss, COGS, and Profitability ratios of the company (ROA, ROE, Net Profit Margin).

a. Relationship

- Average Age of Inventory and Average Collection Period has negative relationship with NPM, ROA, ROE and Profit.

- Average Payment Period has positive relationship with NPM, ROA, ROE and Profit.

- The number of days of late payment has positive relationship with Profit, COGS and ROA.

- The number of days of late payment has negative relationship with NPM and ROE.

- Sales amount of late payment has positive relationship with Profit, COGS, ROA, ROE, and NPM.

b. Significances

- There is significant relationship between sales amounts of late payment with Profit.

- There is significant relationship between sales amounts of late payment with ROA.

- There is significant relationship between sales amounts of late payment with NPM.

2. Interview effort of collecting data through interview of best practice collection activities from other company in same industry and from another industry is found to be unresponded until the study is finalized.

3. Implementable framework and Improvement to KPC for better Account Receivable management and customers control system are:

a. Implement analysis of Risk Quadrant on periodic basis. (Annually, mid annually, monthly)

b. Ensure KPC and Bank both has same perception in recognizing the discrepancies item. For this purpose, LC training delivered by competent trade advisor from Company's bank is urgently needed.

c. Implement reviewing LC using the checklist provided in chapter III to reduce the discrepancy rate.

d. Implement longer time (1 month) review regarding the sufficiency of number of employee that handling invoice and supporting documents. 
Volume 2, Nomor 1, Januari 2022

p-ISSN 2774-7018; e-ISSN 2774-700X

e. Develop credit policy. 


\section{Reference}

Christopher, Martin. (2016). Logistics \& supply chain management. Pearson Uk.

Cornot-Gandolphe, Sylvie. (2014). China's Coal Market-Can Beijing Tame 'King Coal'?

Edmans, Alex. (2011). Does the stock market fully value intangibles? Employee satisfaction and equity prices. Journal of Financial Economics, 101(3), 621-640.

Ganesamoorthy, L., \& Rajavathana, R. (2013). Management of working capital components among select automobile companies in India. Asian Journal of Management, 4(4), 301-307.

Gitman, Dmitri, \& Tyutin, Igor V. (2012). Quantization of fields with constraints. Springer Science \& Business Media.

Gul, Sajid, Khan, Muhammad Bilal, Raheman, S. U., Khan, Muhammad Tauseef, Khan, M., \& Khan, W. (2013). Working capital management and performance of SME sector. European Journal of Business and Management, 5(1), 60-68.

Liang, Fang Yu, Ryvak, Marta, Sayeed, Sara, \& Zhao, Nick. (2012). The role of natural gas as a primary fuel in the near future, including comparisons of acquisition, transmission and waste handling costs of as with competitive alternatives. Chemistry Central Journal, 6(1), 1-24.

Malik, Mohammad Shaukat, \& Bukhari, Mahum. (2014). The impact of working capital management on corporate performance: A study of firms in cement, chemical and engineering sectors of Pakistan. Pakistan Journal of Commerce and Social Sciences (PJCSS), 8(1), 134-148.

Ponsian, Ntui, Chrispina, Kiemi, Tago, Gwatako, \& Mkiibi, Halim. (2014). The effect of working capital management on profitability. International Journal of Economics, Finance and Management Sciences, 2(6), 347-355.

Takon, Samuel Manyo, \& Atseye, Fidelis Anake. (2015). Effect of working capital management on firm profitability in selected Nigerian quoted companies. International Journal of Economics, Commerce and Management, 3(10), 414-438.

Teachout, Zephyr. (2020). Break'em Up: Recovering Our Freedom from Big Ag, Big Tech, and Big Money. All Points Books.

Van der Vliet, Kasper, Reindorp, Matthew J., \& Fransoo, Jan C. (2015). The price of reverse factoring: Financing rates vs. payment delays. European Journal of Operational Research, 242(3), 842-853.

Weil, David. (2014). The fissured workplace. Harvard University Press.

Xia, Yu, \& Tang, Thomas Li-Ping. (2011). Sustainability in supply chain management: suggestions for the auto industry. Management Decision.

Zhao, Stephen, \& Alexandroff, Alan. (2019). Current and future struggles to eliminate coal. Energy Policy, 129, 511-520.

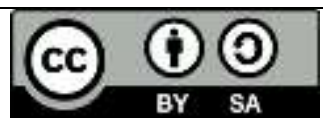

This work is licensed under a Creative Commons Attribution-ShareAlike 4.0 International License. 